\title{
The Impact of Russian Anti-Western Conspiracy Theories on the Status-Related Conflict in Ukraine: The Case of Flight MH17
}

Holger Mölder

TalTech Law School,

Tallinn University of Technology

Akadeemia tee 3 ,

Tallinn 12618, Estonia

E-mail: holger.molder@taltech.ee

Vladimir Sazonov

Ancient Middle Eastern Studies,

University of Tartu

Ülikooli 18,

Tartu 50090, Estonia

E-mail: vladimir.sazonov@ut.ee

Abstract: The Russian Federation has a wide arsenal of tools at its disposal for conducting information warfare to achieve its strategic objectives in the ongoing status conflict with the West. The active exploitation of conspiracy theories has thrived since pro-Kremlin forces started armed conflict against Ukraine in 2013-2014. This article focuses on the crash of Flight MH17, widely used by the Russian media to fabricate various conspiracy theories which make out that the West and Ukraine are responsible for the disaster. This study examines several Russian outlets and TV channels and concludes that the Russian media often used falsified stories and emotional rhetoric in narratives they spread about the crash of Flight MH17. The narratives used to create these conspiracy theories claim that the incident was a Western provocation attempting to generate hostility towards Russia. In disseminating these kinds of conspiracy theories, the proKremlin media created distrust against the West and the Ukrainian government among a larger audience and produced discomfort and disorientation about Western and Ukrainian news. 
Keywords: conspiracy theories, fake news, Flight MH17, information warfare, Russia, status conflict, the West, Ukraine

\section{Introduction: conspiracy theories as an effective tool of information warfare}

Since the evolution of communication networks over the last 25-30 years, of which the internet and social media soon became the most powerful influencers of public opinion globally, more and more conspiracy theories have become available across various types of media outlets, influencing the everyday lives and mindsets of people around the world. The world entered into a post-truth environment where the boundaries between truth and lies, facts and beliefs, became fuzzy and hardly recognizable. New information channels enormously multiplied the number of sources by which information could reach its potential customer and made fake news hardly distinguishable from real ones. Conspiracy theories (CTs) can be spread very fast via social media with the help of the massive and coordinated fabrication of fake news which is skilfully entwined with mainstream news streams (Nissen, 2015). This new environment encouraged the rapid dissemination of politically-motivated conspiracy theories in which personal beliefs successfully compete with objective facts. Interdisciplinary research on conspiracy theories includes various disciplines such as psychology, history, philosophy, semiotics, religious studies, media and communication, and political sciences (see Abalakina-Paap, 1999; Burnett et al., 2005; Clarke, 2002; Coady, 2003; 2006; Dentith, 2014; 2016; Knight, 2002; Macdonald, 2007; Robertson, 2016; Ventsel, 2016).

Russia, whose historical and cultural roots of conspiratorial tradition extend back to the long-gone imperial period (Shinar, 2018), has been among the pioneers of contemporary information warfare and actively started to use different forms of information campaign to further its political goals. During Putin's presidency, anti-Western conspiracy theories became vital instruments for mobilizing supporters of the regime, and simultaneously for discrediting his opponents. Consequently, conspiracy theories became effective tools in modern information warfare, tools actively introduced by the Russian Federation in its hostilities against Ukraine (Mölder \& Sazonov, 2018; Sazonov, 2019b). The current study focuses on a selected sample of the Russian media (e.g., TV channels, news agencies, publications, and digital media) and examines their connection with the conspiracy theories that emerged concerning the catastrophe of Malaysia 
Airlines Flight 17 (MH17) which was shot down on 14 July 2014 during the course of armed conflict between Ukraine and the pro-Kremlin rebels in Donbas. This article argues that the Russian media often turned to anti-Western conspiracy theories in order to support Russian information campaigns against Ukraine and to justify the accusation of responsibility of the West and Ukraine over the downing of Flight MH17.

\section{Methods and data sample}

The term 'conspiracy theory' has been defined as a specific type of communication process (Ventsel, 2016, p. 310) which gives "a proposed explanation of some historical event (or events) in terms of the significant casual agency of a relatively small group of persons - conspirators - acting in secret" (Keeley, 1999 , p. 116). For their analysis, the authors used qualitative content analysis (Kracauer, 1952-1953) of articles published in Russian media outlets and news portals. For this content analysis, we only selected materials about the incident which consist of or could be designated as conspiracy theories. In total, 19 articles $^{1}$ were published from 18 July 2014 to 8 August 2018 in Russian media outlets and news portals in the Russian language: NewsFront, TV Zvezda, Utro. ru, Komsomolskaya Pravda, Tsargrad.tv, Russia Today (RT), Newsland.com and Radio Echo Moskvy, representing a wide spectrum of media sources with various target audiences and impacts, including more marginal and less influential ones like Tsargrad.tv and those which are well-known and influential sources for Russian-speaking audiences in Russia and abroad like Komsomolskaya Pravda or RT. Komsomolskaya Pravda provides nine articles, representing half of the total sample, while each of the other sources provide one or two articles. A period of four years was chosen in order to study the actuality and relevance of the topic (the case of MH17 and conspiracy theories) in Russian information warfare over several years, particularly after the investigation into this catastrophe was begun by international investigators in Europe. This study is supported by some material from the Russian media published in English.

1 The analysed sources include Afanasyev, 2018; Aleksandrova, 2014; Belokonova, 2018; Demchenko, 2014; Komsomolskaya Pravda, 2014; Krakova, 2018; Lagovski, 2014; MK.ru, 2014; Newsland.com, 2018; Polosatov, 2014; Radio Echo Moskvy, 2014; Remizova, Rogoza \& Brusnev, 2015; Russia Today, 2014; Sazonov, 2014; Tsargrad.tv, 2017; Varsegov, 2014; Viktorov, 2018; Zhuravko, 2018a; 2018 b. 


\section{Russia's conspiratorial legacy in the status conflict with the West}

Yablokov (2018) analyses the historical evolution of conspiratorial thinking in Russia from the Imperial period of the 19th century through the whole Soviet period up to the modern day under Putin's presidency and he sets the prosperity of Russian anti-Western conspiracy theories in the period after the Crimean War from 1853 to 1856 which was recognized as a major defeat of Russian policy by the ruling elites. This period was very productive in building a strong image of the West as an adversary. Russia had found itself in a war against major powers in Europe who were allied with the Ottoman Empire, i.e., Great Britain, France and Sardinia (which soon became part of Italy), and the patrioticallyminded elite of the Russian Empire came to the conclusion that, due to Great Britain and its allies turning the war against Russia, the West had betrayed Russia, supported Russia's eternal enemy the Ottoman Empire in this conflict instead and disallowed Russia from gaining new territories. Consequently, the West obtained the image of ultimate and insidious power which seeks ways to undermine Russian progress towards its glorious future.

The narrative of Western conspiracies against Russia did not die with the end of the Russian Empire and in the Soviet Union conspiratorial thinking was a widely practised political tool for keeping society in a constructed information space (The Moscow Times, 2014). During the Soviet era, the belief that Western countries were dreaming of the annihilation and humiliation of the Soviet Union was overwhelmingly disseminated in the society. As follows, many Russian people still believe that a Western plot against the Soviet Union had taken place and that the West deliberately destroyed the USSR. Russian society has always suffered from messianic expectations, a mindset which could also encourage conspiratorial thinking to thrive. In the 19th century, Russia had taken upon itself the role of protector of the Eastern Orthodox Church which should defend Christian minorities living in the Holy Land under the Ottoman Empire. In the ongoing status conflict with the West, Russia also tends to position itself as protector of traditional and conservative values in standing against the assault of Western liberalism and so-called 'gay propaganda' (see Dugin, 1992; Fursov, 2016).

The conflict in Ukraine opened a new phase in the status conflict between Russia and the West (Rácz, 2015; Pabriks \& Kudors, 2015), in which the new Ukrainian government had been assigned the role of a Western puppet after the removal of President Yanukovych. Status conflicts refer to the political environment in 
which powers compete for position and influence in international society (see Forsberg, 2014; Larson \& Shevcenko, 2010; Lebow, 2010; Renshon, 2018; Wohlworth, 2009). Russia has been open-minded in challenging the post-Cold War cooperative international system, seeking higher status among competing powers and developing their status conflict with the West. After the end of the Cold War, Russia kept the status of privileged partner to the West with no real prospect of membership of either NATO or the EU (Trenin, 2006, p. 89).

In the mind of a Russian nationalist with anti-Western views, the West appears as an ultimate and insidious 'Other' seeking to undermine the progress of the Russian nation towards its glorious future (Yablokov, 2015, p. 302). One of the Kremlin's top strategists Vladislav Surkov (2019) has outlined Russia's ideological direction, accentuating that "the state of Russia will continue to exist and will be a new type of country the likes of which we have never seen before". Surkov (2018) emphasizes Russia's strategic goal of modernization without Westernization, which might unravel its strategic mindset while challenging its post-Cold War security governance, which is supported by institutional collaboration on global and regional levels. He describes Russia as a Western-Eastern half-breed nation with a double-headed statehood, hybrid mentality, intercontinental territory and bipolar history, with only two allies-its army and navy (paraphrasing the words attributed to Tsar Alexander III) - and, being alone in this hostile environment, needs to be able to cope with its own strength. Surkov justifies the aggressive policies of President Vladimir Putin and emphasizes that this will be a major new development and a long-term sustained opportunity for the Russian Federation to embody its strategic goals (Sazonov, 2019a).

The anti-Western spirit strengthened in Russian society especially after the beginning of the Russia-Ukraine conflict in 2013-2014. Political spin doctors like Gleb Pavlovsky (chief of the pro-Kremlin Foundation for Effective Politics) and Vladislav Serko (First Deputy Chief of Presidential Administration) drafted a network of educational programs and publishing houses served by pro-Kremlin public intellectuals which carried out anti-Western information campaigns. As a result, conspiratorial thinking was transferred from the margins of Russia's public sphere to the very core of the country's political discourse (Alyukov, 2018). In order to achieve its objectives, Russian propaganda uses quite a wide arsenal of tools in the planning and conducting of information warfare, with the active use of CTs among others (Arold, 2015, p. 14).

According to Krakova (2018) the Russian population is quite susceptible to believing CTs, thinking that there are people who wish to destroy traditional 
Russian spiritual values and re-write Russian history as they believe there exist plots against Russia and secret organizations that want to destroy, harm and humiliate Russia, its culture, orthodoxy and values. In 2018, the staterun Russian Public Opinion Research Centre VTsIOM pollster claimed that $66 \%$ of respondents believe "there is a group of people who seek to rewrite Russian history and replace historical fact in order to hurt Russia and diminish its greatness" and $63 \%$ believe that "a group of people are trying to destroy the spiritual values formed by Russians through the propaganda of non-traditional sexual relations" (The Moscow Times, 2018).

The roots of the ongoing conflict between the Russian Federation and the Ukraine lie in the fall of 2013 when the Ukrainian government led by then President Viktor Yanukovych refused to sign the association agreement with the European Union, which should have intensified trade between them and opened up EU markets to Ukrainian goods. This act was fiercely opposed by the Russian Federation which interpreted the new deal as taking Ukraine away under the Western sphere of influence. Russia was able to pressure Yanukovych to abandon the association agreement, which in turn provoked massive protests in the Maidan square of Kyiv. A large part of Ukrainian society understood the decision made by President Yanukovych and his government as a denial of Ukraine's future in Europe (Vasilyeva, 2018).

Russia's greatest concerns about Ukraine's enhanced partnership with the European Union were caused by their dedication to seeing the world as a battleground. Status-related conflict with the West and identifying the West as an organic adversary to Russia became a dominant political narrative for the Russian elites following economic strengthening during Putin's presidency and his pioneering speech on Security Policy at the Munich Conference in 2007. This narrative identified Western institutions, the European Union among others, as competing adversarial powers to the Russian Federation (Mölder, 2016, pp. 104-106). Moreover, Ukraine has historically always played an essential part in narratives related to Russian nation-building (Müür et al., 2016, p. 31).

Tense relations brought about a new boost to anti-Western conspiracy theories distributed by Russian-controlled information channels. Anti-Western conspiratorial discourse played a pivotal role in explaining Russia's actions during the course of the Ukrainian conflict in 2013/2014 and later. Yablokov (2015, p. 309) claims that Russia's strategic goals in Ukraine are based on the conspiratorial assumption that the US provoked this regime change and toppled President Yanukovych in order to increase Western influence over the postSoviet space. 
Russia's policy towards Ukraine has indicated changes in tactical outcomes while implementing its strategic challenges during the conflict. The annexation of Crimea in 2014 was a successfully completed non-linear attack (Darczewska, 2014) for which the Ukrainian armed forces were not prepared and to which they surrendered without resistance. The war in Donbas manifests a different strategy where a never-ending perpetual war might be the end in itself, and according to which Russia seems to be more interested in destabilization of the post-Soviet space, which Russia often calls its particular "sphere of influence" (Mölder, 2016, pp. 108-109). These strategic challenges were covered by active information campaigns which attempted to shift responsibility for the situation leading to armed conflict from Russia onto the West (Darczewska, 2014).

\section{The MH17 story}

The catastrophe of Flight MH17 was just one of a few occasions when Western involvement in Donbas was evoked by pro-Russian conspiracy theorists (Sazonov, 2019b). In July 2014, heated battles between the Armed Forces of Ukraine and pro-Russian rebels took place in Donbas. Ukrainian units tried to cut off rebel supply lines coming from Russia in the area of Shaktarsk. During the Battle of Shaktarsk, a Malaysian civilian aircraft, carrying the designation of Flight MH1 7 from Amsterdam to Kuala Lumpur, was most probably accidentally shot down in the area. Before the incident, several Ukrainian aircraft were shot down over rebel-controlled territory. Telephone calls made by the rebels and recorded by the Ukrainians led to the conclusion that Boeing 777-200ER had been shot down by mistake as it was thought to be the Ukrainian airplane AN-26 (Dutch Safety Board, 2015).

Nevertheless, Russia actively targeted this tragic event involving a scheduled international passenger flight to promote conspiracy theories, accusing Ukraine and the West of using civilian lives to fuel the War of Donbas (Sazonov, 2019b). These conspiracy theories gained traction from the fact that the crash of Flight MH17 was not the first incident of its type, with a Boeing 777 of Malaysia Airlines (Flight MH370) mysteriously disappearing in March 2014 on its journey from Kuala Lumpur to Beijing, allegedly over the Indian Ocean and far away from its route. No rational explanation has been found to how the plane deviated from such a course, nor any sign to confirm that the plane fell.

The criminal investigation of the MH17 case was led by the Public Prosecution Service of the Dutch Ministry of Justice. Besides the Netherlands, experts from 
Australia, Belgium, Malaysia, and Ukraine participated in the Joint Investigation Team (JIT). The investigation was conducted by the Dutch Safety Board (DSB) and the Dutch-led joint investigation team. A missile was launched from proRussian terrorist-controlled territory in the Eastern part of Ukraine (Dutch Safety Board, 2015). ${ }^{2}$ In September 2016, the JIT released its findings which concluded that the aircraft had been shot down with a 9M38 Buk missile fired from a rebel-controlled airfield near Pervomaisky in the Donetsk Republic. The Buk missile system had been transported from Russia into Ukraine on the day of the crash, and then back into Russia after the crash with one missile fewer than it arrived with (Dutch Safety Board, 2015).

Russian media outlets, TV channels and social media networks (Odnoklassniki, VKontakte, Facebook, Twitter) produced a massive amount of disinformation and multiple conspiracy theories about the crash of Flight MH17 (Sazonov, 2017, pp. 148-149). This particular research, which focused on professional online media outlets, clearly demonstrates that the dissemination of conspiracy theories can be a strong and powerful tool in status-related information warfare. Most of the conspiracy theories shared by these outlets attempted to convince the audience that the West (e.g., the United States, the Netherlands, NATO and the European Union) and Ukraine were responsible for shooting down the aircraft and promoted the image that the crash was a pure Western provocation which aimed to implicate the unrecognized people's republics in Donbas in this crime. Other CTs claimed that Flight MH17 was not in that area at all and it was actually another plane that was shot down instead. One alternative scenario portrayed the event as a terrorist act, making the claim that MH17 exploded because a bomb was detonated inside the aircraft.

The crash of Flight MH17 is a good example of the 'data deluge' method (Arold, 2015 , p. 14) by which the Kremlin's purpose was to disorientate the target audience simultaneously in Russia, Ukraine, and the West (Sazonov, 2015). 'Data deluge' refers to a huge data flood in which a massive amount of diverse content or disinformation is produced and transmitted over various channels of media. Russia uses this method effectively to influence larger audiences with controversial information so as to convince or disorientate the target audience (Mölder \& Sazonov, 2018, p. 323). Russian channels actively deployed and disseminated multiple conspiracy theories about the MH17 incident in order to

2 The investigation was conducted by the Dutch Safety Board and the Dutch-led joint international investigation team. The Dutch side concluded that MH17 had been shot down by a missile (Buk system). This missile was launched from pro-Russian terrorist-controlled territory in the Eastern part of Ukraine. For more see Dutch Safety Board (2015). 
confuse the audience and to cast doubt on official information. Such narratives overwhelmed the audience with a huge amount of information, people being targeted with controversial data and facts, fake stories and conspiracies (Arold, 2015, p. 14). Misperceptions were fabricated and spread among the target audience in order to create a situation where people would stop believing the media completely. The alternative goal was probably to influence the audience through knowing how people often like to believe in conspiracies. Pro-Kremlin information channels used fake, falsified or fabricated stories, witnesses, pictures, and videos with emotional and often sarcastic and offensive rhetoric to produce dozens of theories about by who, how and why Flight MH17 was shot down. The most popular stories claiming Flight MH17 was shot down were related to Ukraine who was made out to be responsible for initiating provocation, with this act of terrorism being ordered by the Ukrainian president Petro Poroshenko himself (see Belokonova, 2018; Newsland.com, 2018; Zhuravko, 2018b; Viktorov, 2018). However, alternative narratives claim that Flight MH17 was shot down by the orders of the CIA or the American government, or that it was even shot down by an Israeli missile (see Sazonov, 2014; MK.ru, 2014; Remizova et al., 2015; Tsargrad.tv, 2017). They conducted several interviews with experts who allegedly possessed secret materials, videos and documents proving that Russia or the pro-Russian republics of Donetsk and Lugansk did not perpetrate the crashing of Flight MH17, but it was instead caused by the involvement of Ukraine and the West (see Komsomolskaya Pravda, 2014; Remizova et al., 2015; Zhuravko, 2018a).

Moreover, Komsomolskaya Pravda has deliberately promoted another incident involving Flight MH370 on March 2014 and referred to paranormal causes like a "hole in time" (Lagovski, 2014). The article in Komsomolskaya Pravda from 24 August 2014 asserts that the same Boeing which disappeared over the Indian Ocean in March 2014 and has the different flight designator 9M-MRO, was shot down in Ukrainian airspace in July 2014 (Varsegov, 2014). Some narratives spread by Russian channels claimed the plane disappeared because of an unidentified flying object (UFO). Other theories tried to convince the public that the crash had been organized by groups aiming to get the New World Order (e.g., Illuminati) to trigger a third world war. Pro-Russian rebel commander Igor Girkin (Strelkov) was quoted as saying: "According to the people who collected the corpses, most of the corpses - "stale"-people have died up to a few days ago" (O’Donoghue, 2017). 


\section{Four conspiracy theories disseminated by the Russian media}

On the basis of a qualitative content analysis, four main outcomes of antiWestern CTs about the case of MH17 have been found. These theories were disseminated by Russian media outlets from July 2014 to August 2018 and have been classified according to the type of party at fault which these theories evoke. However, these four most popular conclusions do not represent the full list of CTs produced in relation to the case of Flight MH17:

1. Ukraine is responsible for the catastrophe of MH17;

2. The MH17 crash was a classic Western provocation against Russia;

3. The United States (or the CIA) shot down MH17;

4. The Netherlands portrayed as guilty.

\section{CT 1: Ukraine is responsible for the catastrophe}

The largest proportion of articles portrayed Ukraine (e.g., state, government, Ukrainian army) as being responsible for the crash of Flight MH17 in Eastern Ukraine. According to this narrative, Ukrainian armed forces were blamed for shooting down Flight MH17 and Ukrainian soldiers, sometimes mentioned by name, were the guilty parties for this catastrophe (see Varsegov, 2014; Polosatov, 2014).

A few days after the crash, Komsomolskaya Pravda produced only a little information about the incident. From 23 July 2014 the situation suddenly changed and Komsomolskaya Pravda began to accuse the Ukrainian armed forces of most probably being responsible for this catastrophe. For example, on the 23rd of July, six days after the crash, an article published by Komsomolskaya Pravda claimed that a Ukrainian soldier named Sergei Patchenko was the most likely culprit who shot down the aircraft (Aleksandrova, 2014). Nevertheless, no serious facts were ever reported to support this claim. Later on, Komsomolskaya Pravda stopped mentioning this name but the narrative accusing Ukraine of forcing down the commercial aircraft continued to be disseminated (Radio Echo Moskvy, 2014).

Stories actively distributed by Russian federal television channels, online, and on social media targeted the audience with confusing and sometimes controversial information. They accused the Ukrainian government (sometimes called a "fascist junta") or President Petro Poroshenko personally of shooting down Flight MH17 (Viktorov, 2018). On 28 May 2018, a former member of the Ukrainian parliament Aleksey Zhuravko (2018b) published an article in 
NewsFront which claimed that, according to rumours in President Poroshenko's close circle, Poroshenko personally gave the Minister of Defence an order to shoot down Flight MH17. The idea that the order to destroy Flight MH17 was given by the President of Ukraine was also promoted by TV Zvezda, which is owned by the Ministry of Defence of the Russian Federation (Newsland. com, 2018; Zhuravko, 2018b). On 17 September 2018, the Russian newspaper Komsomolskaya Pravda published an article about a briefing of the Russian Federation's Ministry of Defence concluding that a Ukrainian missile destroyed Flight MH17 (Belokonova, 2018). Another story in Komsomolskaya Pravda believed that Ukrainian dispatchers changed Flight MH17's planned route and it was because of this that the plane flew into airspace where military actions were taking place (Demchenko, 2014).

On 22 December 2014, Komsomolskaya Pravda (KP) published an article which claimed that Flight MH17 was shot down by the captain of the Ukrainian Army Voloshin. They even found an anonymous witness interviewed by $K P$ who explained how a Ukrainian officer was involved (Komsomolskaya Pravda, 2014). Russian investigators found a witness called Yevgeny Agapov who had allegedly served in the Ukrainian Air Force and confirmed that Flight MH17 had been shot down by Captain Voloshin, who was immediately rewarded by Poroshenko for this act $(R T, 2015)$. Zhuravko (2018b) mentioned that Voloshin later committed suicide in his apartment in Nikolaev.

\section{CT 2: The MH17 crash was a classic Western provocation against Russia}

In Komsomolskaya Pravda, Yevgeny Sazonov (2014) described the case of MH17 as a classic Western provocation against Russia. He claimed that NATO and the United States were interested in sending their troops into Ukraine for, as he put it, "a so-called peacekeeping mission" but Russia did not react to such provocation from the West. And thus the West apparently organized the shooting down of the civilian passenger flight. In order to prevent Western military involvement, Yevgeny Sazonov (2014) proposed preventive intervention from Russia into the conflict area to take responsibility of the defence of the borders along the Luhansk People's Republic and the Donetsk People's Republic.

Tsargrad. $t v^{3}$ promoted a theory that stressed that there had been tight cooperation between the West and Ukraine in organizing a provocation against the pro-

3 Tsargrad.tv is a media group led by a Russian businessman Konstantin Malofeev in cooperation with representatives of the US religious right movement (e.g., the former Fox News employee Jack Hannick). Well-known conservative conspiracy theorists such as Alexandre Dugin or Alex Jones often appear on this channel. 
Kremlin rebels. According to this theory, the West and Ukraine co-organized the shooting down of Flight MH17. Since its very foundation, Tsargrad.tv has been actively propagating anti-Western conspiracy theories, blaming the United States for bombing civilian objects in Iraq since 2003 and for destroying the World Trade Centre buildings in New York on 11 September 2001 (Tsargrad. $t v, 2017)$.

\section{CT 3: The United States (or the CIA) shot down MH17}

Several articles published by the Russian media claimed that Flight MH17 was destroyed due to the detonation of a bomb by claiming that the crash was an act of terrorism organized by the US Central Intelligence Agency (CIA); the CIA was also, however, directly accused of shooting down the airplane (Remizova et al., 2015).

On 17 December 2017, the Russian media channel Tsargrad.tv introduced this idea and published an article with the title 'Boeing in the air above Donbas was shot down by the order of the US', in which the author pointed out that tests concerning the crash of Flight MH17 were performed in laboratories in the United States and Lithuania, countries already engaged in developing hostility against Russia. According to this article, there exists no proof which could confirm that the Russian missile system Buk shot down Flight MH17 (Tsargrad. $t v, 2017)$. This article defends Russia and blames the West, especially the US, for "dirty deals" by underlining the fact that neither the Russian Federation nor pro-Russian rebels have any motive for this crime, whereas the pro-Western regime in Kyiv has great interest in discrediting fighters in Donbas who oppose the Nazi-friendly dictatorship (Tsargrad.tv, 2017).

An article published on 12 August 2015 in Komsomolskaya Pravda referred to information which came from Sergey Sokolov, a former security guard of Russian oligarch Boris Berezovski, who was working for a private detective agency. He and his colleagues allegedly investigated secret materials called "17.17" and came to the conclusion that this crash in Eastern Ukraine gave every indication of being a secret CIA operation (Remizova et al., 2015). The federal information agency Analitika and Bezopasnost ('Analyses and Security') called upon Sergey Sokolov to present his own version of events which, according to the article, had not been previously considered. Sokolov assumed the crash was a special operation conducted by Western secret services and that Flight MH17 was destroyed by a bomb placed on board. 


\section{CT 4: The Netherlands portrayed as guilty}

Although this narrative was mostly disseminated by fringe portals and outlets such as the information agency of the Russian public movement "Renaissance. The Golden Era", it has still been widely used in Russian media and social media. This conspiracy theory relies on obvious facts such as how Flight MH17 was flying from Amsterdam to Kuala Lumpur, which makes the Netherlands and its government easy targets for conspiratorial accusations together with the fact that the government of the Netherlands started an investigation into the crash of Flight MH17.

Some materials that were published assert that the passengers' fate was sealed when the Boeing was "dropped down", while the Netherlands and Ukraine have been accused of trying to sabotage the FIFA World Cup 2018 tournament (Afanasyev, 2018). Yuri Antipov, who identifies himself as an independent technical expert, supports the theory that Flight MH17 was destroyed by explosives stowed aboard the aircraft and he criticizes theories that a missile could have destroyed Flight MH17 (Remizova et al., 2015). Antipov presented his theory which claims that there were more bombs on board the aircraft. $\mathrm{He}$ postulates:

All witnesses say they heard several explosions in the air. Some witnesses say they heard two explosions, others mention three. But the Russian system 'Buk'can make just one explosion... If it ever has to be proven the plane was blown up, the Netherlands will be fully responsible for the fact that a plane took off from their airport with a bomb on board. (Remizova et al., 2015)

Narratives promoted by the Russian media also affected Western conspiracy theorists. American writer and historian Eric Zuesse is convinced that Ukraine should be blamed for downing the Malaysian aircraft and that the West is lying in order to keep the EU and US anti-Russian sanctions in place. Zuesse (2018) brings up the fact that Russian claims this airliner was shot down by the Ukrainian Government have been ignored by the US-allied news media which is attempting to cover up what he calls "actual evidence". He incriminates the Netherlands government in partially funding the coup of February 2014 which overturned Ukraine's government and installed the new regime in its place. 


\section{Conclusion}

The conflict in Ukraine which broke out in 2013-2014 immediately became part of an enhanced status-related conflict between the Russian Federation and the West. Anti-Western feelings emerged and started to attract the political elites of the Russian Empire after the Crimean War of the mid-19th century, a time when many prominent representatives of the Russian elites felt themselves betrayed by the West. Since then, Russia has started to promote more forcefully the idea of Russia as a unique civilization suffering under constant attack from the West in their secret aim to govern the whole world. During the Soviet regime, conspiracy theories about the West reached their peak in official propaganda, but these misperceptions did not dissipate along with the dissolution of the Soviet Union as Russia continued its civilizational battles.

The vast majority of conspiracy theories presented in this content analysis blame Ukraine for the incident. The rest portray the West, the United States and more rarely the Netherlands as responsible for the catastrophe of Flight MH17. Nevertheless, almost all the narratives disseminated by the Russian media concerning Flight MH17 firmly prove its link to the status conflict between Russia and the West, which is strategically promoted by the Russian Federation in its attempt to increase the impact it has on international relations. In this conflict, Ukraine has been portrayed as a puppet state which is heavily dependent on its Western hosts. Such articles often feature interviews with people who allegedly possess secret materials on the MH17 crash which prove that Russia and pro-Russian rebels could not possibly have organized this crash, and that it was done by Ukraine and the West.

The crash of Flight MH17 represents just another case of a tragic event incurring real losses about which the Russian media has intentionally distributed fabricated news and stories in order to disorientate and confuse the audience, using it as a propagandistic tool against the Ukrainian government to portray it as weak and unreliable. A strong anti-Western component has also been retained in the rhetoric of these fabricated narratives around the event. Samples from the Russian media have attempted to create a kind of illusion of Western provocation directed against the Russian Federation and pro-Russian rebels in Donbass, in which Ukraine was sided with the West, in order to accuse them of this crime.

Dr. Holger Mölder is an associate professor in international relations at the Department of Law at Tallinn University of Technology. Since 2018, he is a member of COST ACTION 
15101: Comparative Analysis of Conspiracy Theories, which is an interdisciplinary and international network to provide a comprehensive understanding on conspiracy theories. His research fields focus on international security studies, but he has also published on a wide range of fields from US and British politics to Russian, Middle-Eastern and LatinAmerican policy issues, among others. His recent projects focus on information warfare and hybrid warfare. He defended his $\mathrm{PhD}$ dissertation in political sciences Cooperative Security Dilemma_Practising the Hobbesian Security Culture in the Kantian Security Environment in 2010 at the University of Tartu.

Dr. Vladimir Sazonov is a senior research fellow in Ancient Middle Eastern studies at the University of Tartu and in information operations at the Estonian Military Academy. Since 2017, he is vice-president of the Estonian Academic Oriental Society. Since 2018, he is a member of COST ACTION 15101: Comparative Analysis of Conspiracy Theories, which is an interdisciplinary and international network to provide a comprehensive understanding on conspiracy theories. His research fields range from ancient Near Eastern cultures and history to modern Middle East and Russian politics and information warfare. In 2010, he defended his PhD (in history) on royal titles and epithets in Assyria, the Hittite Empire and North Syria (Ugarit, Emar, Karkemiš) in the Middle-Assyrian period at the University of Tartu.

\section{References}

Abalakina-Paap, M.; Stephan, W. G.; Craig, T. \& Gregory, W. L. (1999), 'Beliefs in conspiracies,' Political Psychology, vol. 20, pp. 637-647. https://doi.org/10.1111/0162-895X.00160

Afanasyev, A. (2018), 'Gollandtsy "sbrosili" Boing MH17 na chempionat mira po futbolu' [Dutch people "threw" Boeing MH17 on FIFA World cup], Tsargrad. tv, 24 May. Retrieved from https://tsargrad.tv/articles/gollandcy-sbrosili-boingmh17-na-chempionat-mira-po-futbolu_134423 [accessed 4 Jan 2019]

Aleksandrova, O. (2014), 'Soldata ukrainskoy armii zatravili za foto na fone "Buka" [Soldier of Ukrainian army was baited because of a photo with "Buk"], Komsomolskaya Pravda, 23 July. Retrieved from http://kompravda.eu/ daily/26259/3138276/ [accessed 2 Sep 2018]

Alyukov, M. (2018), 'Conspiracy theory has gone mainstream in Russia. But how does it work?' Open Democracy, 7 September. Retrieved from https://www. opendemocracy.net/od-russia/maxim-alyukov/conspiracy-theory-has-gonemainstream-in-russia [accessed $22 \mathrm{Feb} 2019]$

Arold, U. (2015), 'Infosõja mõistatus' [Mystery of information war], Kaja, Kommunikatsiooni ja suhtekorralduse ajakiri, vol. 18, pp. 9-14. 
Belokonova, E. (2018), 'Minoborony: sbivshaya “Boing” nad Donbassom raketa stoyala na vooruzhenii ukrainskoy armii' [Ministry of Defence: missile which shot down Boeing in Donbas was used by Ukrainian armed forces], Komsomolskaya Pravda, 17 September. Retrieved from https://www.kompravda.eu/daily/26882/3926318/ [accessed 1 Mar 2019]

Burnett, Th. et al. (2005), Conspiracy Encyclopedia: The Encyclopedia of Conspiracy Theories, London: Collins \& Brown.

Clarke, S. (2002), 'Conspiracy theories and conspiracy theorizing,' Philosophy of the Social Sciences, no. 2, pp. 131-150. https://doi.org/10.1177/004931032002001

Coady, D. (2003), 'Conspiracy theories and official stories,' International Journal of Applied Philosophy, vol. 17, pp. 197-209. https://doi.org/10.5840/ijap200317210

Coady, D. (2006), 'The pragmatic rejection of conspiracy theories,' in D. Coady (ed.) Conspiracy Theories: The Philosophical Debate, Hampshire: Ashgate, pp. 167-170. https://doi.org/10.4324/9781315259574-13

Darczewska, J. (2014), 'The anatomy of Russian information warfare: the Crimean operation, a case study,' Point of View, no. 42 (May 2014), Warsaw: Ośrodek Studiów Wschodnich im. Marka Karpia.

Demchenko, V. (2014), 'Ukrainskie dispetchert izmenili marshrut pogibshego lainera, i on letel nad rayonom boyevih deistvij' [Ukrainian dispatchers changed route of MH17 an it was flying over war zone], Komsomolskaya Pravda, 18 July. Retrieved from https://www.kompravda.eu/daily/26257/3136622/ [accessed 12 Feb 2019]

Dentith, M. (2014), The Philosophy of Conspiracy Theories, New York: Palgrave. https://doi.org/10.1057/9781137363169

Dentith, M. (2016), 'When inferring to a conspiracy might be the best explanation,' Social Epistemology, vol. 31, nos. 5-6, pp. 572-591. https://doi.org/10.1080/02691728.2016.1172362

Dugin, A. (1992), Konspirologiya [Conspirology], Moscow: Evraziya.

Dutch Safety Board (2015), 'MH17 Crash'. Retrieved from https://www.webcitation. org/6cFSGnsRg?url=http://cdn.onderzoeksraad.nl/documents/report-mh17-crashen.pdf [accessed 25 Feb 2019]

Forsberg, T. (2014), 'Status conflicts between Russia and the West: Perceptions and emotional biases,' Communist and Post-Communist Studies, vol. 47, nos. 3-4, pp. 323-331. https://doi.org/10.1016/j.postcomstud.2014.09.006

Fursov, A. I. (2016), Mirovaya bor'ba. Anglosaksy portiv planety [World Fighting. Anglosaxons against Planet], Moscow: Knizhnyi mir.

Keeley, B. L. (1999), 'Of conspiracy theories,' Journal of Philosophy, no. 3, pp. 109-126. https://doi.org/10.2307/2564659

Knight, P. (2002), Conspiracy Nation. The Politics of Paranoia in Postwar America, New York \& London: New York University Press. 
Knott, P. (2018), 'Meet the most dangerous man in the world,' The New European, 21 September. Retrieved from https://www.theneweuropean.co.uk/top-stories/mostdangerous-man-world-paul-knott-putin-fascist-philosopher-1-5703698 [accessed 18 Apr 2019]

Komsomolskaya Pravda (2014), 'Malaziyskiy "Boing” sbil ukrainskiy lyotchik - kapitan Voloshin' [Malaysian Boeing was shoot down by Ukrainian pilot Captain Voloshin], 22 December. Retrieved from https://www.kompravda.eu/ daily/26323.5/3204312/ [accessed 2 Sep 2018]

Kracauer, S. (1952-1953), 'The challenge of qualitative content analysis,' The Public Opinion Quarterly, Special Issue on International Communications Research, vol. 16, no. 4, pp. 631-642. https://doi.org/10.1086/266427

Krakova, S. (2018), 'Mirovaya zakulisa: otkuda poyavilsya "zagovor portiv Rossii", [World backstage: from where originated "conspiracy against Russia"], Gazeta.ru, 21 August. Retrieved from https://www.gazeta.ru/business/2018/08/21/11903245. shtml [accessed 27 Feb 2019]

Lagovski, V. (2014), 'Malaziyskiy “Boing” provalilsya v dyru vo vremeni?' [Did Malaysian Boeing disappear in a time hole?], Komsomolskaya Pravda, 25 March. Retrieved from https://www.kompravda.eu/daily/26210/3095390/ [accessed 28 Feb 2019]

Larson, D. W. \& Shevcenko, A. (2010), 'Status seekers: Chinese and Russian responses to US primacy,' International Security, vol. 34, no. 4, pp. 63-95. https://doi. org/10.1162/isec.2010.34.4.63

Lebow, R. (2010), 'The past and future of war, presented as the E. H. Carr lecture, University of Wales,' International Relations, vol. 24, no. 3, pp. 1-28. https://doi.org/10.1177/0047117810377277

Macdonald, S. (2007), Propaganda and Information Warfare in the Twenty-First Century: Altered Images and Deception Operations, New York: Routledge. https://doi.org/10.4324/9780203967393

MK.ru (2014), 'Propavshiy v mare malaziyskiy Boung mogli sbit' voennye SSHA, opasayas' terakta' [The Malaysian Boeing which disappeared in March might have been shot down by US military forces, who fear terrorist act], 22 December. Retrieved from https://www.mk.ru/incident/2014/12/22/propavshiy-v-marte-malayziyskiyboeing-mogli-sbit-voennye-ssha-opasayas-terakta.html [accessed 27 Feb 2019]

Mölder, H. \& Sazonov, V. (2018), 'Information warfare as the Hobbesian concept of modern times - principles, techniques and tools of Russian information operations in Donbass,' Journal of Slavic Military Studies, vol. 31, no. 3, pp. 308-328. https:// doi.org/10.1080/13518046.2018.1487204

Mölder, H. (2016), ‘The war of narratives - Putin's challenge to international security governance in Ukraine,' Sõjateadlane (Estonian Journal of Military Studies), vol. 6 , no. 2 , pp. 88-113. 
Müür, K.; Mölder, H.; Sazonov, V. \& Pruulman-Vengerfeldt, P. (2016), 'Russian information operations against the Ukrainian state and defence forces: AprilDecember 2014 in online news,' Journal of Baltic Security, vol. 2, no. 1, pp. 28-71. https://doi.org/10.1515/jobs-2016-0029

Newsland.com (2018), 'Prikaz sbit' malaziyskiy Boing otdal lichno Proshenko' [The order to shot down Malaysian Boeing was given by Poroshenko personally], 1 April. Retrieved from https://newsland.com/community/4109/content/prikaz-sbitmalaziiskii-boing-otdal-lichno-poroshenko/6280527 [accessed 1 Mar 2019]

Nissen, Th. E. (2015), The Weaponization of Social Media, Copenhagen: Royal Danish Defence College. Retrieved from http:/www.fak.dk/publikationer/Documents/ The $\% 20$ Weaponization $\% 20$ of\%20Social\%20Media.pdf?pdfdl=theweaponization ofsocialmedia?pdfdl= TheWeaponizationOfSocialMedia [accessed 28 Feb 2019]

O'Donoghue, R. (2017), “They were dead BEFORE it crashed': Shock claim about doomed Flight MH17,' Daily Star, 17 July. Retrieved from https:/www.dailystar. co.uk/news/latest-news/630114/flight-mh17-malaysian-airlines-mh370-putincorpses [accessed 19 Apr 2019]

Pabriks, A. \& Kudors, A., eds. (2015), The War in Ukraine: Lessons for Europe, The Centre for East European Policy Studies, Rīga: University of Latvia Press.

Polosatov, S. (2014), 'Poyavisya snimok, na kotorom ukraisnkiy istrebitel' atakuet malaziyskiy "Boing" [A photo emerged on which a Ukrainian fighter is attacking Malaysian Boeing], Komsomolskaya Pravda, 24 November. Retrieved from http://kompravda.eu/daily/26307/3186146/ [accessed 6 Nov 2018]

Rácz, A. (2015), Russia's Hybrid War in Ukraine: Breaking the Enemy's Ability to Resist, Helsinki: The Finnish Institute of International Affairs.

Radio Echo Moskvy (2014), 'Komsomolskaya Pravda: Malaziyskiy Boing byl sbit v nebe nad Donbasom ukrainskim lyotchikom' [Komsomolskaya Pravda: Malaysian Boeing was shot down in Donbas by a Ukrainian pilot], 23 December. Retrieved from http://echo.msk.ru/news/1460870-echo/comments.html [accessed 11 Aug 2018]

Remizova, M.; Rogoza, A. \& Brusnev, M. (2015), 'Versiya: "Boing” vzorvala zalozhannaya vnutri bomba' [Version: Boeing was blown up by a bomb inside the plane], Komsomolskaya Pravda, 12 August. Retrieved from https://www. kompravda.eu/daily/26419.3/3291610/ [accessed 4 Jan 2019]

Renshon, J. (2017), Fighting for Status: Hierarchy and Conflict in World Politics, Princeton, NJ: Princeton University Press. https://doi.org/10.23943/ princeton/9780691174501.001.0001

Robertson, D. G. (2016), UFOs, Conspiracy Theories, and the New Age. Millennial Conspiracism, London: Bloomsbury Academic.

Russia Today (2014), 'Britanskie SMI: Propavshiy nad Indiyskim okeanom samolyot Malaysia Airlines byl sbiy voennimy SSHA' [British media: The Malaysia Airlines 
plane gone missing in Indian Ocean was shoot down by US military forces], 22 December. Retrieved from https://russian.rt.com/article/65845 [accessed 27 Feb 2019]

Russia Today (2015), 'Russian investigators reveal identity of key witness in MH17 crash,' 3 June. Retrieved from https://www.rt.com/news/264545-mh17investigators-key-witness/ [accessed 21 Apr 2019]

Sazonov, J. (2014), "Nestykovki i zagadki malaziyskogo "Boinga", [Secrets of Malaysian Boeing], Komsomolskaya Pravda, 18 July. Retrieved from https:// www.kompravda.eu/daily/26257/3136728/ [accessed 04 Jan 2019]

Sazonov, V. (2015), Interview with D. Kuleba carried out by Vladimir Sazonov, 27 May 2015 in Kyiv.

Sazonov, V. (2017), 'Examples of criticism towards Ukraine based on materials from Komsomolskaya Pravda,' ENDC Occasional Papers, vol. 7, pp. 148-149.

Sazonov, V. (2019a), 'Moscow's Minsk gambit: can Russia swallow Belarus?' Diplomaatia, no. 187. Retrieved from https://icds.ee/moscows-minsk-gambit-canrussia-swallow-belarus/ [accessed: 21 April 2019]

Sazonov, V. (2019b), 'Some notes on Russian conspiracy theories as a part of the information war in Ukraine: the case of MH17,' Security Forum, vol. 3, no. 1, pp. $45-56$.

Shinar, Ch. (2018), 'Conspiracy narratives in Russian politics: from Stalin to Putin,' European Review, vol. 26, no. 4, pp. 648-660. https://doi.org/10.1017/S1062798718000376

Surkov, V. (2018), The Loneliness of the Half-Breed: Russia in Global Affairs, 28 May. Retrieved from https://eng.globalaffairs.ru/book/The-Loneliness-of-the-HalfBreed-19575 [accessed 8 Jul 2018]

Surkov, V. (2019), 'Dolgoye gosudarstvo Putina' [Long state of Putin], Nezavisimaya gazeta, 11 February. Retrieved from www.ng.ru/ideas/2019-02-11/5_7503_surkov. html [accessed 15 Apr 2019]

The Moscow Times (2014), 'Theory blaming West for collapse of Soviet Union gaining in popularity,' 2 December. Retrieved from https://www.themoscowtimes. com/2014/12/02/theory-blaming-west-for-collapse-of-soviet-union-gaining-inpopularity-poll-shows [accessed $22 \mathrm{Feb} 2019$ ]

The Moscow Times (2018), 'Two-thirds of Russians believe in broad anti-Russia conspiracy, poll says,' 20 August. Retrieved from https://www.themoscowtimes. com/2018/08/20/two-third-of-russians-believe-in-broad-anti-russia-conspiracypoll-says-a62579 [accessed 18 Apr 2019]

Trenin, D. (2006), 'Russia leaves the West,' Foreign Affairs, vol. 85, no. 4, pp. 87-96. https://doi.org/10.2307/20032043

Tsargrad.tv (2017), “'Boing” v nebe nad Donbassom sbili po prikazu iz SSHA' [Boeing in Donbas was shoot down by order of the US], 9 December. Retrieved from https:// 
tsargrad.tv/articles/boing-v-nebe-nad-donbassom-sbili-po-prikazu-iz-ssha_99766 [accessed 4 Jan 2019]

Varsegov, N. (2014), 'Ukrainskiye pushki byut po mestu kastastrofy "Boinga" chto by ne dat' rabotat' gollandskim specialistam' [Ukrainian canons shoot at the crash site of Boeing to impede the work of Dutch specialists], Komsomolskaya Pravda, 10 November. Retrieved from http://kompravda.eu/daily/26305.5/3183895 [accessed 8 Sep 2018]

Vasilyeva, N. (2018), 'Russia's conflict with Ukraine: an explainer,' Military Times, 26 November. Retrieved from https://www.militarytimes.com/news/yourmilitary/2018/11/26/russias-conflict-with-ukraine-an-explainer/ [accessed $18 \mathrm{Apr}$ 2019]

Ventsel, A. (2016), 'Political potentiality of conspiracy theories,' Lexia, vol. 23/24, pp. 309-326.

Viktorov, N. (2018), 'Malaziyskiy "Boing" sbili vmestio lainera s rossiyanami' [Malaysian Boeing was shot down instead of a plane carrying Russians], Utro.ru, 8 August. Retrieved from https://utro.ru/life/2018/08/08/1369845.shtml, [accessed 1 Mar 2019]

Wohlworth, W. C. (2009), 'Unipolarity, status competition, and great power,' World Politics, vol. 61, no. 1, pp. 28-57. https://doi.org/10.1017/S0043887109000021

Yablokov, I. (2015), 'Conspiracy theories as a Russian public diplomacy tool: the case of Russia Today (RT),' Politics, vol. 35, no. 3-4, pp. 301-315. https://doi. org/10.1111/1467-9256.12097

Yablokov, I. (2018), Fortress Russia: Conspiracy Theories in the Post-Soviet World, Cambridge, UK \& Medford, MA: Polity. https://doi.org/10.1093/oso/9780190844073.003.0024

Zhuravko, A. (2018a), 'Boing-777 reysa MH17 sbila vlast' fashistov...' [Boeing-777 of MH 17 was shot down by fascist power], NewsFront, 28 May. Retrieved from https://news-front.info/2018/05/28/aleksej-zhuravko-boing-777-rejsa-mn17sbila-vlast-fashistov-v-ukraine/ [accessed 1 Mar 2019]

Zhuravko, A. (2018b), 'Poroshenko lichno otdal prikaz sbit Boeing v Donbasse - byvshii deputat Rady' [Poroshenko personally gave an order to shoot down Boeing in Donbas: a former member of Ukrainian parliament], TV Zvezda, 4 June. Retrieved from https://tvzvezda.ru/news/vstrane_i_mire/content/201806041709s1ft.htm [accessed 1 Mar 2019]

Zuesse, E. (2018), 'MH17 turnabout: Ukraine's guilt now proven,' Strategic Culture Foundation, 31 December. Retrieved from https://www.strategic-culture.org/ news/2018/12/31/mh17-turnabout-ukraine-guilt-now-proven.html [accessed 18 Apr 2019] 